\title{
Pemetaan Penyebaran dan Prediksi Jumlah Penduduk Menggunakan Model Geometrik di Wilayah Bandar Lampung Berbasis Web-GIS
}

\author{
Yuni Rahayu' ${ }^{1)}$, Kurnia Muludi' ${ }^{2}$, Astria Hijriani ${ }^{3)}$ \\ ${ }^{122) 3)}$ Jurusan Ilmu Komputer FMIPA Unila \\ Jln. Soemantri Brojonegoro, Bandar Lampung \\ 1)yunirahayu446@gmail.com \\ ${ }^{2) k m u l u d i @ y a h o o . c o m ~}$ \\ 3)astria.hijriani@gmail.com
}

\begin{abstract}
Abstrak - Pengamatan pola penyebaran penduduk merupakan salah satu hal yang sangat penting bagi pemerintah. Informasi mengenai hal ini akan bermanfaat untuk pengambilan keputusan dalam perencanaan pembangunan di wilayah pemerintahan. Prediksi penyebaran jumlah penduduk akan sangat bermanfaat untuk perencanaan pembangunan di wilayah Bandar Lampung. Informasi mengenai penyebaran dan prediksi jumlah penduduk di wilayah Bandar Lampung masih diolah secara manual dengan penyajian masih terbatas dalam bentuk tabel dan grafik. Penelitian ini bertujuan untuk membangun sistem informasi geografis berbasis web yang menampilkan pemetaan penyebaran dan prediksi jumlah penduduk berdasarkan metode geometrik di wilayah Bandar Lampung. Data pada penelitian ini diperoleh dari publikasi Badan Pusat Statistik Kota Bandar Lampung. Sistem ini diimplementasikan menggunakan Qgis, Geoserver, PostgreSQL dan bahasa pemrograman PHP. Hasil keseluruhan pengujian menunjukkan bahwa sistem informasi geografis penyebaran dan prediksi jumlah penduduk telah sesuai baik dari segi fungsionalitasnya, maupun dari segi interaksi pelayanan pengguna.
\end{abstract}

Kata Kunci-Sistem Informasi Geografis, Model Geometrik, Pemetaan Jumlah Penduduk.

Abstract - Population distribution pattern is one of Bandar Lampung government concerns. This information is useful for goverment decision making for specific local development.The prediction of population number using certain model is predicted will be useful for Bandar Lampung development plan. Information about distribution and prediction of resident population in Bandar Lampung are processed manually and limitedly presented in form of tables and graphs. The purpose of this research is to build Bandar Lampung web based Geographic Information System that predict population distribution and mapping using Geometric Model. Data in this research were obtained from Statistics Of Bandar Lampung Municipality Publication. This system was implemented by using QGIS, GeoServer, PostgreSQL and PHP programming language. Overall,the testing results show that the system is appropriate and functional.

Keywords - Geographic information system, Geometric Model, Mapping population.

Article history:

Received 10 May 2016; Received in revised form 28 July 2016 \& 10 August 2016; Accepted 10 August 2016; Available online 28 October 2016

\section{PENDAHULUAN}

Pengamatan pola penyebaran penduduk disuatu daerah digunakan agar pemerintah dapat mengambil keputusan yang tepat untuk melakukan pembangunan di daerah tersebut sesuai dengan jumlah penduduk yang ada. Hasil prediksi jumlah penduduk akan bermanfaat untuk perencanaan pembangunan di segala bidang. Salah satu cara untuk memprediksikan jumlah penduduk di suatu wilayah adalah dengan menggunakan model pertumbuhan penduduk geometrik.

Penelitian sebelumnya, (Setyorini, 2012) telah melakukan analisis terhadap kepadatan penduduk dan proyeksi kebutuhan permukiman kecamatan depok sleman tahun 2010-2015 menggunakan model geometrik, namun penyajian data sebaran dan data prediksi masih diproses secara manual dan ditampilkan dalam bentuk tabel dan grafik, maka dari itu perlu dilakukan pengembangan terhadap proses dan penyajiannya seperti menggunakan sistem informasi geografis. Penelitian menggunakan metode pertumbuhan geometrik juga dilakukan oleh indrawati dkk. untuk mengetahui proyeksi tingkat partisipasi angkatan kerja dan tingkat pengangguran di provinsi Sumatra Selatan (Indrawati, Faruk, \& Susanti, 2013), Namun pada penelitian tersebut penyajian data hasil proyeksi kurang maksimal, karena hanya dalam bentuk tabel.

Informasi mengenai penyebaran dan prediksi jumlah penduduk di wilayah Bandar Lampung masih diolah secara manual dengan penyajian masih terbatas dalam bentuk tabel dan grafik. Penyajian dalam bentuk peta akan membantu proses pengamatan pola penyebaran penduduk dengan lebih mudah. Sistem Informasi Geografis (SIG) atau geohraphic information system (GIS) 
adalah sebuah sistem yang didesain untuk menangkap, menyimpan, memanipulasi, menganalisa, mengatur, dan menampilkan seluruh jenis data geografi (Irwansyah, 2013).

(Ural, Hussain, \& Shan, 2011) telah melakukan penelitian untuk membangun SIG tentang pemetaan jumlah penduduk, pada penelitian ini pemetaan populasi penduduk dilakukan berdasarkan hasil dari citra satelit dan juga hasil sensus penduduk, namun karena peta yang digunakan hanya dari citra satelit maka penyajian data dalam bentuk petanya kurang maksimal. Penelitian yang dilakukan oleh (Santosa, Sofyan, \& Widiyastuti, 2008) tentang sistem informasi geografis penyebaran penduduk berdasarkan tingkat usia di kabupaten sleman berbasis web menghasilkan program SIG berbasis web dengan peta kartografi yang dapat menunjukkan persebaran penduduk. Namun sistem ini tidak menyediakan tools untuk melakukan ataupun menampilkan proyeksi jumlah penduduk melainkan hanya menampilkan peta sebaran jumlah penduduk saja.

Penelitian untuk membangun SIG berbasis WEB di Bandar Lampung juga telah dilakukan oleh (Muludi, Irawati, \& Falianingrum, 2013) yaitu tentang Perancangan WEB-GIS Penyebaran Wabah Penyakit Demam Berdarah Dengue (DBD) dan Malaria di Kota Bandar Lampung, sedangkan yang membahas tentang kependudukan belum dilakukan. Berdasarkan permasalahan dan juga dengan adanya penelitian penelitian sebelumnya, maka akan dibangun sistem informasi geografis berbasis web (Web-Geographic Information System) yang dapat digunakan untuk memberikan informasi berupa pemetaan penyebaran jumlah penduduk dan juga menampilkan prediksi jumlah penduduk berdasarkan metode geometrik di wilayah Bandar Lampung.

Penelitian ini merupakan bagian dari roadmap penelitian untuk kelompok penelitian data spasial dan Decision Support System. Sistem ini diharapkan mampu mempermudah penyampaian informasi mengenai penyebaran jumlah penduduk di wilayah Bandar Lampung dan dapat menampilkan prediksi perubahan distribusi jumlah penduduk di wilayah Bandar Lampung. Manfaat dari sistem ini adalah untuk mempermudah masyarakat dalam memperoleh data lokasi penyebaran jumlah penduduk dan kepadatan penduduk di Kota Bandar Lampung. Perubahan distribusi penyebaran jumlah penduduk di wilayah Bandar Lampung yang ditampilkan dapat membantu pemerintah dalam pengambilan keputusan untuk perencanaan pembangunan dimasa yang akan datang.

\section{METODOLOGI PENELITIAN}

Pembangunan sistem ini menggunakan metode waterfall. Waterfall software process model atau linier sequential model merupakan model klasik yang bersifat sistematis, yang artinya berurutan atau secara linier dalam membangun software, jika satu langkah belum dikerjakan maka langkah berikutnya tidak dapat dikerjakan (Pressman, 2010). Metode Waterfall cocok digunakan untuk proyek berskala kecil, ukuran proyek dikatakan kecil jika dikerjakan dalam waktu kurang dari 6 bulan dan hanya dilakukan oleh kurang dari 3 orang (Palacios-Marques, Soriano, \& Huang, 2015). Penelitian ini merupakan proyek berukuran kecil sehingga cocok menggunakan metode Waterfall. Diagram alir dari pembangunan sistem ini ditunjukkan pada gambar 1 .

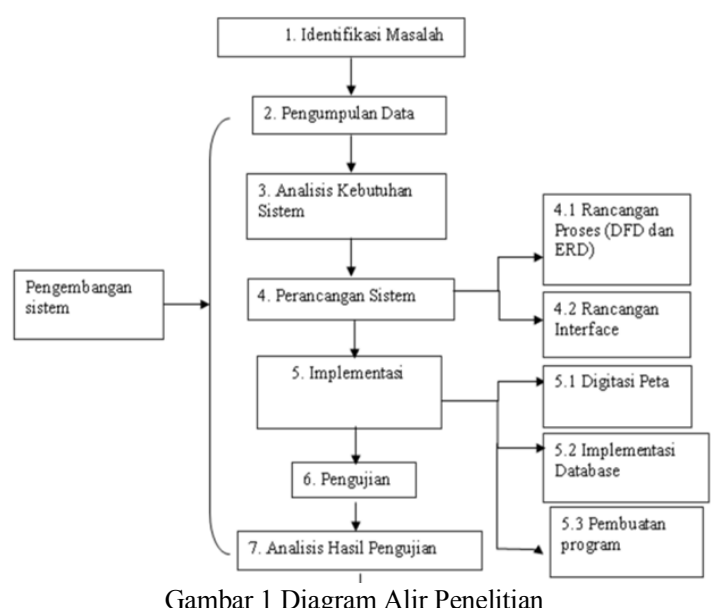

\section{A. Identifikasi Masalah}

Identifikasi masalah merupakan langkah pertama yang dilakukan untuk mengidentifikasi dan menganalisis permasalahan yang ada. Pada langkah ini akan menghasilkan rumusan masalah, batasan masalah, tujuan penelitian, dan juga manfaaat penelitian.

\section{B. Pengumpulan Data}

Pegumpulan data pada penelitian ini menggunakan metode studi literatur yang didapat dari buku atau jurnal mengenai penelitian sejenis. Studi literatur mengenai data kependudukan diperoleh dari PST (Pelayanan Statistik Terpadu) BPS Bandar Lampung dan BPS Provinsi Lampung.

\section{Analisis Kebutuhan Sistem}

Analisis kebutuhan dilakukan untuk menentukan kebutuhan dari pengguna. Analisis kebutuhan untuk pembangunan SIG pemetaan jumlah penduduk terdiri dari analisis kebutuhan fungsional dan kebutuhan non fungsional. Kebutuhan fungsional dari SIG pemetaan penyebaran penduduk adalah sebagai berikut.

a. Sistem dapat menampilkan peta penyebaran penduduk berdasarkan tahun dan kelurahan di wilayah Bandar Lampung.

b. Sistem dapat menampilkan prediksi jumlah penduduk ditahun yang akan datang. 
Kebutuhan non fungsional dari SIG pemetaan penyebaran penduduk adalah sebagai berikut.

1) Operasional

a. Dapat digunakan pada sistem operasi Windows 7 atau linux

b. Spesifikasi komputer minimum Intel ${ }^{\circledR}$ Celeron

c. Menggunakan Geoserver sebagai server pengolah peta

d. Menggunakan database PostgreSQL.

e. Compatible di semua web browser, khususnya Mozila firefox atau Google chrome.

2) Keamanan

a. Hak akses sistem untuk administrator dibatasi dan dilengkapi dengan password.

3) Informasi

a. Informasi yang disediakan berupa informasi mengenai data kependudukan dan sebaran petanya.

b. Informasi penanganan kesalahan (error handling) dilakukan ketika terjadi kesalahan proses input data.

4) Kinerja

a. Perhitungan prediksi dilakukan dengan selisih tahun dari tahun dasar sampai tahun akhir minimal lebih dari 1 tahun.

b. Waktu eksekusi untuk menampilkan peta disesuaikan dengan kecepatan jaringan internet yang ada.

c. Mampu menyimpan data dalam jumlah yang besar.

\section{Perancangan Sistem}

Tahap ini akan menerjemahkan syarat kebutuhan ke sebuah perancangan atau pemodelan (software design) yang dapat diperkirakan sebelum dilakukan coding. Perancangan pada sistem ini terdiri menjadi dua bagian yaitu rancangan proses dan rancangan interface. Rancangan proses pada pembangunan sistem ini menggunakan data flow diagram (DFD) dan Entity Relationship Diagram (ERD) sebagai rancangan database yang akan dibuat.

Data Flow Diagram (DFD) merupakan model grafikal sistem yang menunjukkan semua kebutuhan utama suatu sistem informasi pada satu diagram yang didalamnya terdapat penjelasan mengenai input dan output serta proses dan penyimpanan data, sedangkan Entity Relationship Diagram (ERD) adalah gambar atau diagram yang menunjukkan informasi dibuat, disimpan dan digunakan dalam sistem bisnis (Al Fatta, 2007).

\section{E. Implementasi}

Implementasi dari hasil perancangan yang telah dibuat terdiri dari beberapa tahap, yaitu.

- Digitasi Peta
Digitasi peta Bandar Lampung dilakukan dengan menggunakan aplikasi Quantum Gis.

- Implementasi Database

Database yang digunakan untuk pembangunan sistem ini adalah aplikasi basis data postgreSQL dan phpPgAdmin.

- Pembuatan Program

Sistem ini akan dibangun menggunakan bahasa pemrograman PHP dan Html.

Data yang dibutuhkan dalam sistem ini terdiri data spasial dan data non-spasial (angka data penyebaran). Data spasial merupakan data hasil digitasi peta kelurahan Bandar Lampung dengan menggunakan Quantum Gis yang kemudian dikonversi kedalam PostgreSQL sehingga menghasilkan tipe data Geometry. PostgreSQL memungkinkan setiap user untuk membuat sendiri object file yang dapat diterapkan untuk mendefenisikan tipe data, fungsi dan bahasa pemrograman yang baru sehingga PostgreSQL sangat mudah dikembangkan maupun di implementasikan pada tingkat user (Obe \& Hsu, PostgreSQL: Up and Running. California: O'Reilly Media, 2012). Untuk mengkonversi data spasial ke dalam PostgreSQL membutuhkan ekstensi PostGIS. PostGis adalah sebuah database spasial berbasis open source sebagai ekstensi dari PostgreSQL yang digunakan untuk meng-inputkan data spasial ke dalam PostgreSQL (Obe \& Hsu, 2011).

\section{F. Pengujian}

Pengujian (testing) dilakukan setelah proses pengkodean selesai. Testing untuk sistem ini akan menggunakan metode pengujian fungsional sistem (Blackbox testing) dan juga menggunakan WebQual 4.0.

\section{G. Analisis Hasil Pengujian}

Analisis hasil pengujian merupakan analisis dari hasil pengujian yang telah dilakukan. Hal ini dilakukan untuk menganalisis kesalahan yang mungkin terjadi saat pengujian sistem dan melakukan perbaikan atas kesalahan tersebut.

\section{HASIL DAN PEMBAHASAN}

Data spasial yang telah dikoversi ke database PostgreSQL memerlukan konfigurasi dari layerlayer yang ingin ditampilkan sehingga peta terlihat pada browser. Proses konfigurasi layer ini dilakukan dengan menggunakan geoserver. Geoserver adalah tipe perangkat lunak server yang lengkap dan yang dapat mempublikasikan data ke dalam aplikasi map mapping (Lacovella, 2014), namun sebelum melakukan konfigurasi layer dengan geoserver perlu ditentukan terlebih dahulu tabel distribusi frekuensinya, yaitu penyusunan data kedalam kelas-kelas interval. Tujuannya adalah untuk membuat uraian dari data yang telah diperoleh dan menampilkan dalam bentuk stastistik sederhana sehingga masyarakat dapat 
lebih mudah mendapatkan gambaran tentang situasi dari penyebaran jumlah penduduk di wilayah Bandar Lampung.

Pertama, perlu diketahui jumlah kelas yang harus dibuat dan menentukan berapa panjang interval setiap kelasnya. Hal ini membantu dalam mendistribusikan nilai-nilai yang ada pada data. Rumus untuk menentukan jumlah kelas adalah sebagai berikut (Susanti, 2010).

$$
\mathrm{K}=1+3,3 \log \mathrm{N}
$$

Jumlah kelas yang diperoleh berdasarkan pada rumus (1) dengan jumlah data (N) 126 kelurahan adalah sebagai berikut:

$$
\begin{aligned}
\mathrm{K} & =1+3,3 \log \mathrm{N} \\
& =1+3,3 \log 126 \\
& =1+3,3(2,10) \\
& =1+6,93 \\
& =7,93 \approx 8 \text { kelas }
\end{aligned}
$$

Jumlah kelas dari data penyebaran ini adalah 7,93 dan dibulatkan menjadi 8 kelas. Setelah jumlah kelas diperoleh maka perlu dihitung interval disetiap kelasnya. Interval kelas dihitung menggunakan rumus berikut (Susanti, 2010)

$$
\mathrm{C}=\frac{\text { data terbesar }- \text { data terkecil }}{\mathrm{K}}
$$

Interval kelas pada penelitian ini dihitung dengan mengambil sampel dari data jumlah penduduk Bandar Lampung tahun 2012. Nilai data terkecil untuk jumlah penduduk adalah 1223 jiwa, dan nilai data terbesar jumlah penduduk adalah 15876 jiwa sedangkan nilai data terkecil untuk kepadatan penduduk adalah 186 jiwa $/ \mathrm{km}^{2}$, dan nilai data terbesar kepadatan penduduk adalah $45394 \mathrm{jiwa} / \mathrm{km}^{2}$. Interval kelas untuk kelas jumlah penduduk berdasarkan rumus 2 adalah sebagai berikut:

$$
\begin{aligned}
\mathrm{C}_{\mathrm{jp}} & =\frac{\text { data terbesar-data terkecil }}{\mathrm{K}} \\
& =\frac{15876-1223}{8} \\
& =1831,625 \approx 1832 \text { jiwa }
\end{aligned}
$$

Interval kelas untuk kelas kepadatan penduduk yang juga dihitung dengan rumus 2 adalah sebagai berikut:

$$
\begin{aligned}
\mathrm{C}_{\mathrm{kp}} & =\frac{\text { data terbesar }- \text { data terkecil }}{\mathrm{K}} \\
& =\frac{45394-186}{8} \\
& =5651 \mathrm{jiwa} / \mathrm{Km}^{2}
\end{aligned}
$$

Tabel distribusi frekuensi untuk penyebaran jumlah penduduk yang diperoleh berdasarkan hasil perhitungan dengan jumlah kelas $(\mathrm{K})$ adalah 8 kelas dan interval kelas jumlah penduduk 1832 disetiap kelasnya ditunjukkan pada Tabel 1 .
TABEL 1 DISTRIBUSI TINGKAT KELAS JUMLAH PENDUDUK

\begin{tabular}{|l|l|}
\hline Kelas & Jumlah penduduk \\
\hline I & $0-1832$ jiwa \\
\hline II & $1833-3665$ jiwa \\
\hline III & $3666-5498$ jiwa \\
\hline IV & $5499-7331$ jiwa \\
\hline V & $7332-9164$ jiwa \\
\hline VI & $9165-10997$ jiwa \\
\hline VII & $10998-12830$ jiwa \\
\hline VIII & $>12830$ jiwa \\
\hline
\end{tabular}

Tabel distribusi frekuensi untuk tingkat kepadatan jumlah penduduk yang diperoleh berdasarkan hasil perhitungan dengan jumlah kelas $(\mathrm{K})$ adalah 8 kelas dan interval kelas kepadatan penduduk 5651 disetiap kelasnya ditunjukkan pada Tabel 2.

TABEL 1 DISTRIBUSI TINGKAT KELAS KEPADATAN PENDUDUK

\begin{tabular}{|l|l|}
\hline Kelas & Jumlah penduduk \\
\hline I & $0-5651 \mathrm{jiwa} / \mathrm{Km}^{2}$ \\
\hline II & $5652-11303 \mathrm{jiwa} / \mathrm{Km}^{2}$ \\
\hline III & $11304-16955 \mathrm{jiwa} / \mathrm{Km}^{2}$ \\
\hline IV & $16956-22607 \mathrm{jiwa} / \mathrm{Km}^{2}$ \\
\hline V & $22608-28259 \mathrm{jiwa} / \mathrm{Km}^{2}$ \\
\hline VI & $28260-33911 \mathrm{jiwa} / \mathrm{Km}^{2}$ \\
\hline VII & $33912-39563 \mathrm{jiwa} / \mathrm{Km}^{2}$ \\
\hline VIII & $>39563 \mathrm{jiwa} / \mathrm{Km}^{2}$ \\
\hline
\end{tabular}

Sistem informasi geografis penyebaran dan prediksi jumlah penduduk di wilayah Bandar Lampung diimplementasikan dengan menggunakan bahasa pemrograman PHP dan HTML serta geoserver sebagai server pengolahan peta. Implementasi sistem dihasilkan berdasarkan perancangan DFD dan ERD sebelumnya.Halaman lihat peta sebaran jumlah penduduk dari sistem ini ditunjukkan pada gambar 5 .

Pengguna akan diberikan form untuk memilih tahun yang ingin ditampilkan peta sebaran penduduknya. Prediksi jumlah penduduk dihitung dengan metode geometrik, yaitu dengan memperhitungkan pertumbuhan penduduk hanya pada akhir tahun dari suatu periode. Rumus untuk menghitung prediksi jumlah penduduk pada tahun tertentu adalah sebagai berikut (Susanti, 2010)

$$
\mathrm{P}_{\mathrm{t}}=\mathrm{P}_{0}(1+\mathrm{r})^{\mathrm{tp}}
$$

$P_{t}$ merupakan Jumlah penduduk pada tahun $t$, $P_{0}$ adalah Jumlah penduduk tahun dasar, $r$ adalah Laju pertumbuhan penduduk dan $t_{p}=$ Periode waktu antara tahun dasar sampai tahun prediksi.

Tahapan yang dilakukan adalah menghitung estimasi penduduk menggunakan laju pertumbuhan penduduk (growth rates) kemudian menghitung prediksi jumlah penduduk di masa depan berdasarkan laju pertumbuhan yang telah di peroleh. Estimasi laju pertumbuhan penduduk berdasarkan Rumus 3 dengan $t$ adalah selisih 
tahun antara tahun saat ini dan tahun dasar dapat dihitung menggunakan rumus berikut (BPS, 2014)

$$
r=\left(\frac{P_{t}}{P_{0}}\right)^{\frac{1}{t}}-1
$$

Pengguna akan diminta untuk mengisi tahun yang ingin diprediksi, kemudian memilih tahun dasar dan tahun akhir yang telah ada, setelah itu sistem akan langsung menampilkan hasil perhitungan ke dalam tabel dan pengguna harus menekan tombol simpan jika ingin menyimpan data tersebut ke database.

Sistem ini juga menampilkan peta perındingan sebaran penduduk antara data pada tahun prediksi dengan data yang ada. Hal ini dilakukan agar pengguna dapat melihat perubahan keadaan jumlah penduduk yang terjadi disetiap tahun. Tampilan dari halaman hitung prediksi ditunjukkan pada gambar 6, sedangkan halaman perbandingan peta ditunjukkan pada gambar 7 .
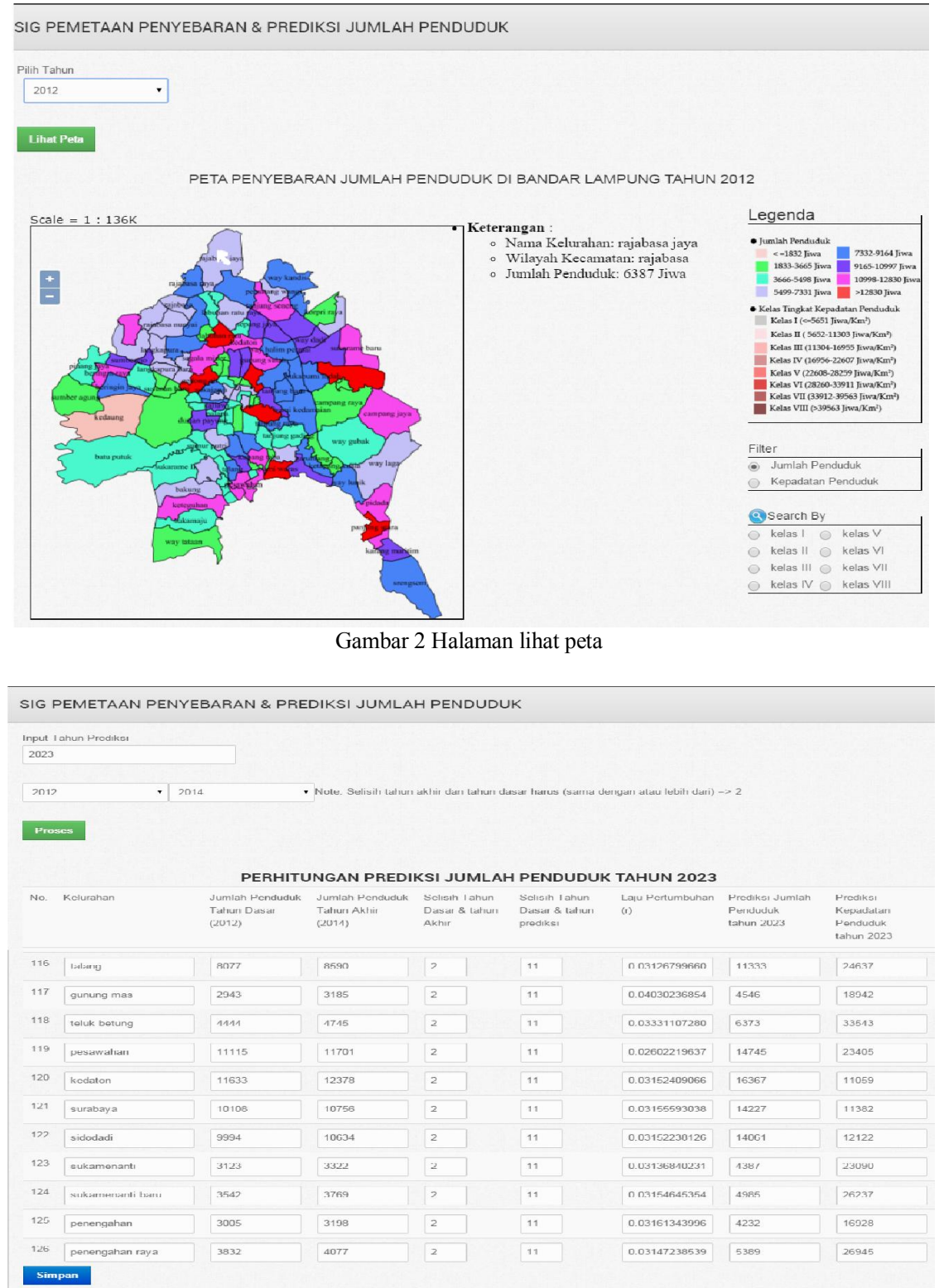

Gambar 3 Halaman hitung prediksi 


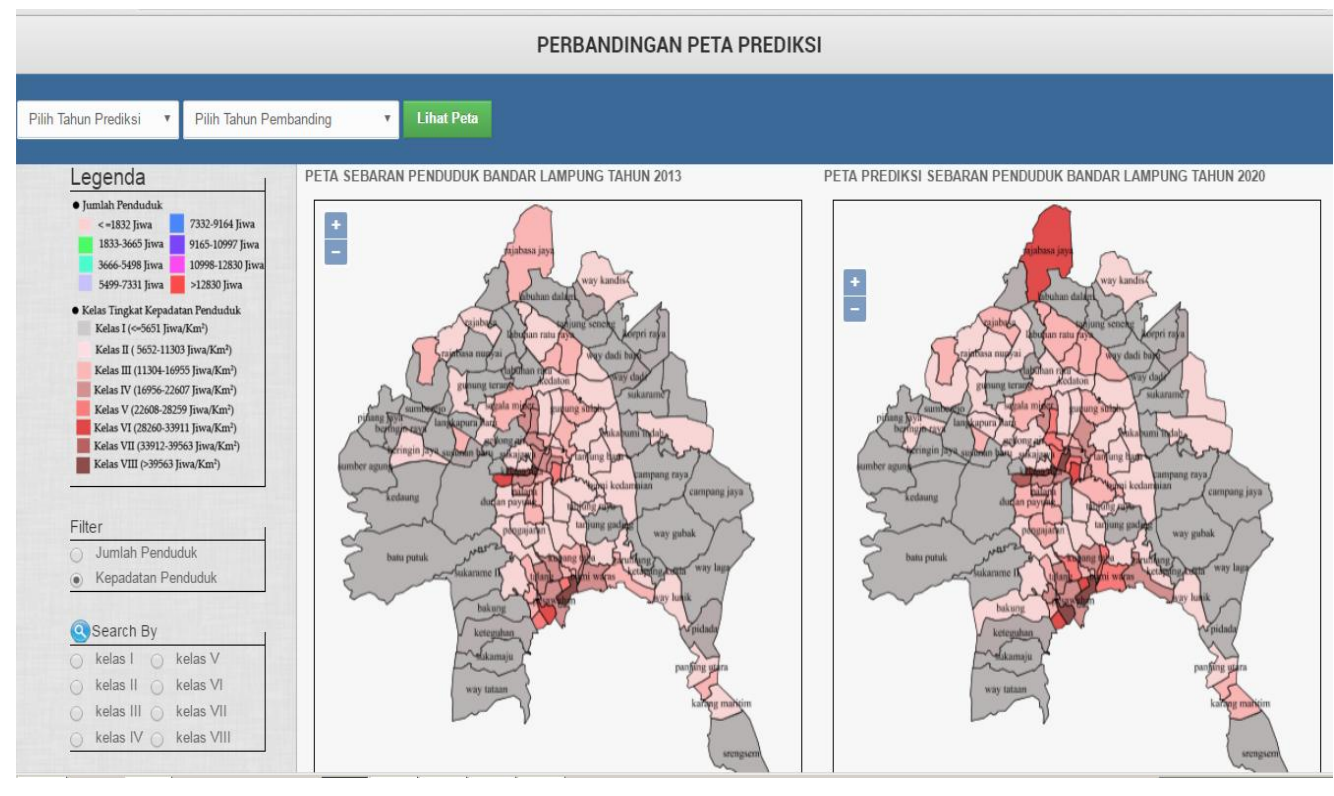

Gambar 4 Halaman perbandingan peta

Pengujian pada sistem ini menggunakan dua metode yaitu pengujian fungsional berdasarkan metode black box testing dan pengujian interaksi layanan sistem berdasarkan webQual. Black Box Testing (pengujian kotak hitam) yaitu menguji perangkat lunak dari segi spesifikasi fungsional tanpa menguji desain dan kode program (Sukamto \& Salahuddin, 2011). Pengujian fungsional sistem dilakukan oleh pihak BPS kota Bandar Lampung dengan data penduduk dari tahun 2012 sampai tahun 2013. Hasil pengujian fungsional sistem menunjukan bahwa hasil yang sebenarnya telah sesuai dengan hasil yang diharapkan, sedangkan untuk pengujian WebQual dilakukan oleh 30 responden sebagai pengunjung web. Hasil pengujian WebQual menunjukkan bahwa dari kriteria kemudahan penggunaan sistem telah sesuai dengan tingkat persentase jawaban "sesuai" dari empat kriteria jawaban sebanyak $46,25 \%$, begitu juga dengan kriteria kualitas informasi yang disajikan sistem sangat baik, dan mudah dipahami oleh pengguna dengan tingkat persentase jawaban "sesuai" dari empat kriteria jawaban sebanyak 56,67\%. Sistem ini juga telah cukup sesuai dari segi kriteria interaksi layanan sistem dengan pengguna dengan tingkat persentase jawaban "cukup sesuai" dari empat kriteria jawaban sebanyak $58,09 \%$. Keseluruhan hasil pengujian menunjukkan bahwa sistem informasi geografis penyebaran dan prediksi jumlah penduduk telah sesuai baik dari segi fungsionalitasnya, maupun dari segi interaksi pelayanan pengguna.

\section{KESIMPULAN}

Kesimpulan yang didapat berdasarkan penelitian yang telah dilakukan yaitu sistem informasi geografis pemetaan dan penyebaran prediksi jumlah penduduk telah dibuat sesuai dengan analisis dan perancangan.

Keseluruhan hasil pengujian menggunakan metode black box testing dan juga WebQual 4.0 menunjukkan bahwa sistem informasi geografis penyebaran dan prediksi jumlah penduduk telah sesuai baik dari segi fungsionalitasnya, maupun dari segi interaksi pelayanan pengguna.

Sistem ini dapat digunakan untuk memudahkan proses pengamatan pe-nyebaran dan prediksi jumlah Penduduk di wilayah Bandar Lampung menggunakan model pertumbuhan geometrik.

Saran diberikan untuk melengkapi beberapa kekurangan yang terdapat dalam sistem ini, maka dari itu untuk pengembangan selanjutnya perlu memperhatikan beberapa rekomendasi berikut. Menambah model prediksi yang digunakan seperti model aritmatika, eksponensial maupun regresi linear sebagai pembanding hasil prediksi, Memberikan fungsi tambahan untuk mencetak peta digital yang dihasilkan, Menambahkan faslilitas export data dan peta dalam format standar ESRI (misal .shp file ).

\section{DAFTAR PUSTAKA}

Al Fatta, H. (2007). Analisis dan Perancangan Sistem Informasi untuk Keunggulan Bersaing dan Organisasi Modern. Yogyakarta: Andi.

BPS. (2014). Proyeksi Penduduk Lampung 20102035 dan Kabupaten/Kota 2010-2020. Bandar Lampung: Badan Pusat Statistik.

Indrawati, Faruk, A., \& Susanti, D. (2013). Proyeksi Tingkat Partisipasi Angkatan Kerja dan Tingkat Pengangguran di Provinsi Sumatra Selatan Dengan Metode Ekstrapolasi dan Pertumbuhan Geometri. Seminar Nasional 
Matematika dan Aplikasinya (pp. 580-584). Surabaya: Universitas Airlangga.

Irwansyah, E. (2013). Sistem Informasi Geografis: Prinsip Dasar dan Pengembangan Aplikasi. Yogyakarta: DigiBook.

Lacovella, S. (2014). GeoServer Cookbook. United Kingdom. Birmingham: B3 2P B.

Muludi, K., Irawati, A. R., \& Falianingrum, A. (2013). Perancangan WEB-GIS Penyebaran Wabah Penyakit Demam Berdarah Dengue (DBD). Jurnal Komputasi , 1 (1), 15-25.

Obe, R. O., \& Hsu, L. S. (2011). PostGis In Action. California: O'Reilly Media.

Obe, R., \& Hsu, L. S. (2012). PostgreSQL: Up and Running. California: O'Reilly Media. California: O'Reilly Media.

Palacios-Marques, D., Soriano, D. R., \& Huang, K. H. (2015). New Information Communication Technologies For Knowledge Management In Organization. Switzerland: Springer.

Pressman, R. S. (2010). Software Engineering A Practitioner's Approach (7nd Edition ed.). New York: McGraw-Hill Companies.
Santosa, B., Sofyan, H., \& Widiyastuti, W. A. (2008). Sistem Informasi Geografis Penyebaran Penduduk Berdasarkan Tinkat Usia Di Kabupaten Sleman Berbasis Web. Seminar Nasional Informatika 2008 (pp. 47-54). Yogyakarta: UPN Yogyakarta.

Setyorini, B. (2012). Analisis Kebutuhan Peduduk dan Proyeksi Kebutuhan Pemukiman Kecamatan Depok Sleman tahun 2010-2015. Skripsi, Universitas Muhammadiyah Surakarta, Fakultas Geografi.

Sukamto, R. A., \& Salahuddin, M. (2011). Modul Pembelajaran Rekayasa Perangkat Lunak. Bandung: Modula.

Susanti, M. N. (2010). Statistika Deskriptif Induktif. Yogyakarta: Graha Ilmu.

Ural, S., Hussain, E., \& Shan, J. (2011). Building population mapping with aerial imagery and GIS data. International Journal of Applied Earth Observation and Geoinformation , 13 (6), 841-852. 